\title{
Impact on feeding and growth rate of millipedes and their conservation needs in Cauvery Delta Region of Kumbakonam, Tamil Nadu
}

\begin{abstract}
Diplopoda (millipedes) is one of the largest classes of animal kingdom belonging to the Devonian period constituting the third largest group after Insecta and Arachnida in terrestrial arthropods. These diplopods play an ample role in soil formation being involved both physical and chemical factors. In addition, millipedes can be as a bio-indicator for environmental changes in ecosystems. A study on millipedes such as Yellow-spotted (Harpaphe haydeniana), Red-spined (Xenobolus carnifes), Colossal slender spined (Spinotarsus colosseus) and American giant, (Narceus americanus) were conducted along the bank of Cauvery River in Kumbakonam region. The present study is intended to find out to know the impact on food intake and the growth rate of millipedes by artificial feeding of decomposed dry leaves and the amount of milli casts (faecal) produced of millipedes under captive condition.

The experiment was carried out during the monsoon season and hand picking of millipedes were done. Ten numbers each of four species of millipedes were kept in separate plastic jars. Dry and decayed leaves were weighed and kept inside the plastic jar as food for millipedes. Before starting the experiment all the individuals of the millipedes were weighed separately and inserted in to the jars. The milli cast deposited by millipedes were separated and weighed to know the production of amount of milli casts. In the case of Harpaphe haydeniana the increase of body weight of 10 individuals shows that there is significant differences between the individuals $(\mathrm{F}=0.1308, \mathrm{df}=8.141, \mathrm{p}=0.9969)$. Xenobolus carnifex shows that there is about $25 \%$ of the weight increase among the individuals $(\mathrm{F}=0.1385$, $\mathrm{df}=8.134, \mathrm{p}=0.9962$ ). Spinotarsus colosseus the increase of body weight of 10 individuals shows that there is a significant differences between the individuals $(\mathrm{F}=0.05101, \mathrm{df}=8.142$, $\mathrm{p}=0.9999$ ). Narceus americanus the 90 days period of experiment shows that there is about $25 \%$ of the weight increase among the individuals $(\mathrm{F}=0.1308, \mathrm{df}=8.141, \mathrm{p}=0.9969)$. It is suggested that the results of this experiment can be applied to millipedes in their natural setting, further confirming millipedes as important components of soil ecosystems and nutrient cycling.
\end{abstract}

Keywords: millipedes, body weight, food intake, milli cast, conservation, Cauvery
Volume 6 Issue 6 - 2019

\author{
Veeramani A, Ramkumar R, Keerthika M \\ PG and Research Department of Zoology, Government Arts \\ College (Autonomous), India
}

\begin{abstract}
Correspondence: Veeramani A, PG and Research Department of Zoology, Government Arts College (Autonomous), Kumbakonam, 612 002, Tamil Nadu, India, Tel 8I2488I520, Email wildvera@gmail.com
\end{abstract}

Received: August 24, 2019 | Published: December 05, 2019

\section{Introduction}

The saprophagous macrofauna (eg. millipedes, earthworms, slugs) are mainly responsible for increased nutrient leaching from dead plant organic matter and enhancement of soil humification. ${ }^{1,2}$ Diplopoda (millipedes) is one of the largest classes of animal kingdom belonging to the Devonian period constituting the third largest group after Insecta and Arachnida in terrestrial arthropods. ${ }^{3,4}$ Based on the body structure, five morphotypes have been identified in millipedes by Kime \& Golovatch ${ }^{5}$. Polyxemda (bristly millipedes or barkdwellers), Glomenda (pill millipedes or rollers), Julida (bulldozers or rammers), Polydesmida (wedge or litter-splitters) and Platydesmida (borers). Millipedes occupy three major habitats in forest ecosystem (the aerial part of vegetation, bark and rotten woody stumps, litter and soil strata). ${ }^{6}$

Similarly, they also exhibit horizontal distribution depending on the diversity and quantity of plant litter on the forest floor or soil. Unlike earthworms and woodhce, millipedes are conservative and very sensitive to water deficit and fail to overcome the limitation of even a single edaphic factor (eg soil texture, litter thickness) although rest of the ecological conditions are conducive. ${ }^{5}$ Millipedes are more abundant in Western Ghat forests than in grasslands or coastal habits due to relative abundance of litter biomass. ${ }^{7,8}$
These diplopods play an ample role in soil formation being involved both physical and chemical factors. Physical disruption of the upper layer of the soil and the litter noticeably enhances the burrowing activities of both adult and larval stadia. Many immature stadial durations are completed in the humus layer of the soil itself. Chemical influences of these animals on soil are of several kinds (1) modification of plant material through digestion (2) uptake and concentration of calcium and other minerals and (3) release of nitrogenous compounds from metabolic excretion and formation of weak organic acids as the result of death and protein breakdown. ${ }^{9}$ South Indian millipedes are known to feed on soil and litter in varying stages of decomposition. Most of the tropical millipedes are known to aestivate during drought, their distribution and period of activity are dependent on humidity and water resources of the soil. Many of these also feed on green vegetable matter and in the absence of the litter they switch over to utilization of soil, rich in rotting organic matter.

Millipedes are functionally important in facilitating nutrient cycling and decomposition of dead plant tissues. In addition, millipedes can be a bioindicators for environmental changes in ecosystems. There is no study on millipedes were reported in the Cauvery delta region, even though we have many species of millipedes present here. There is a study on diversity of millipedes were reported in Alagar 
Hill Reserved Forest, Madurai by Alagesan \& Ramanathan ${ }^{10}$. Apart from this studies are meager in Tamil Nadu particularly in Cauvery delta region. Hence a study on millipedes such as Yellow-spotted (Harpaphe haydeniana), Red-spined (Xenobolus carnifes), Colossal slender spined (Spinotarsus colosseus) and American giant, (Narceus americanus) were conducted along the bank of Cauvery River in Kumbakonam region with the objectives of the growth rate of four different species of millipedes under captive condition, food intake of millipedes by artificial feeding of decomposed dry leaves and the amount of milli casts (faecal) produced by four different millipede species.

\section{Materials and methods}

Kumbakonam is located at $10.97^{\circ} \mathrm{N} 79.42^{\circ} \mathrm{E}$. It lies in the region called the "Old delta" which comprises the north-western taluks of Thanjavur district that have been naturally irrigated by the waters of the Cauvery and its tributaries for centuries in contrast to the "New Delta" comprising the southern taluks that were brought under irrigation by the construction of the Grand Anicut canal and the Vadavar canal in 1934. It has an average elevation of 26 metres. The town is bounded by two rivers, the Cauvery River on the north and Arasalar River on the south (Figure 1).

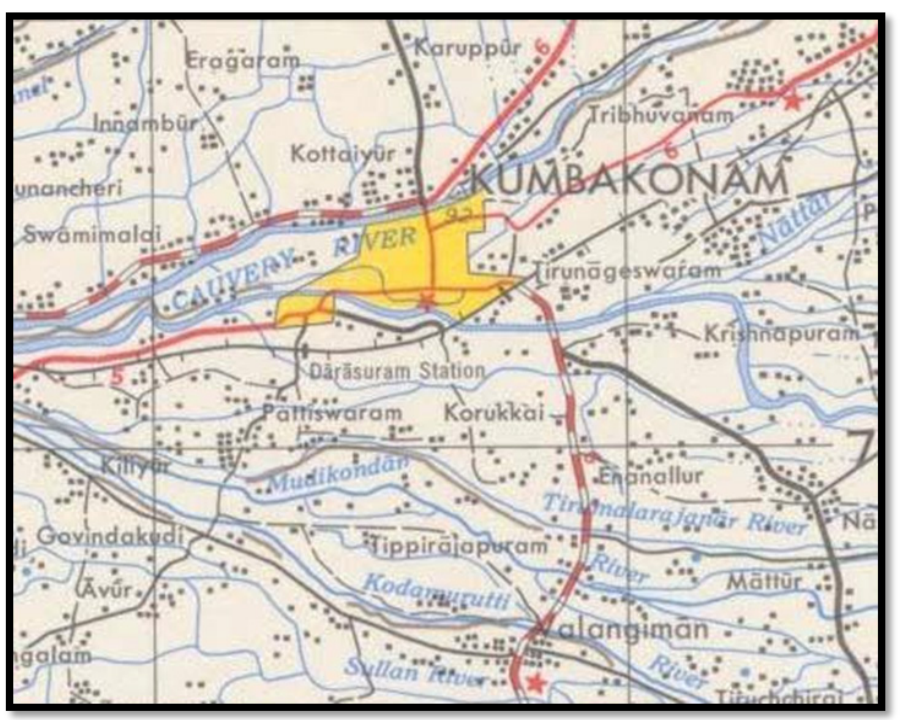

Figure I Map of Cauvery delta at Kumbakonam and surroundings.

The experiment was carried out during the north-west monsoon (December-January) and post monsoon (February and March) when millipedes are available in large numbers. Hand picking of millipedes were carried out to conduct the experiment. The experiment consisted of 10 numbers each of four species of millipedes were kept in separate plastic jars. Dry and decaye d leaves were weighed and kept inside the plastic jar as food for millipede. Although spraying of water are also done to keep the cool environment. The experiment helps to assess no-choice of feeding of captive millipedes under laboratory condition. After the initiation period, the millipedes were allowed to feed the diets.

\section{Set-up of the experiments}

Plastic jars with well-fitting perforated lids were used for this experiment. Jars were large enough to contain the amount of air needed for the millipede to breathe normally during a 24-h period. Before starting the experiment all the individuals of the millipedes were weighed separately and inserted in to the jars. Regular weight of the millipedes was taken to know the growth. Similarly same quantity of dry and decayed leaves were weighed and kept inside the jars and water was sprayed for make wet of the leaves. Feed was given whenever the leaves were fed by millipedes. Care was taken to provide same quantity of leaves at every time. Every 15 days of interval the unfed leaves were weighed and removed. The faeces (milli cast) deposited by millipedes were separated and weighed to know the production of amount of milli casts. The same procedure was continued till the end of the experiment. Digital weighing balance was used to estimate the accurate weight of millipedes and feed.

Based on these experiment, data were collected on amount of food intake and milli cast produced by millipedes. Also the increasing trend of body weight of millipedes was also collected. Care was taken to remove and weighing of the millipedes, because of some imperfections such as defensive body secretions on the tweezers and water condensation on the tweezers' fingers may have occurred. The average difference between the calculated weight of all the species of millipedes was used to correct the directly measured weight gain.

In order to calculate the consumption index (CI) the formula of Waldbauer ${ }^{11}$ was slightly modified:

$$
C I=\text { intake } /[(\text { initial weight }+ \text { final weight }) / 2]
$$

The efficiency of conversion of ingested food (ECI; \%) into body substance of the millipedes of each jar was calculated using Equation $2: 11,12$

$$
E C I=100[\text { weight gain }(\text { ing }) / \text { intake }(\text { in } g)]
$$

Initial body weight per 10 millipedes (at $\mathrm{t}=0$ ), their weight after 15 days (at $\mathrm{t}=15$ ), food intake, body weight gain, and CI and ECI were calculated. The computer programme PAST and MINITABT was used for the statistical analyses.

\section{Results}

\section{Growth rate}

The results collected for 90 days from mid December 2019 to mid March 2019 on four species of millipedes shows that there is a considerable increase of growth from the initial and final weight of the experiment. In the case of Harpaphe haydeniana the increase of body weight of 10 individuals shows that there is significant differences between the individuals $(\mathrm{F}=0.1308, \mathrm{df}=8.141, \mathrm{p}=0.9969)$. Similarly more than $50 \%$ of the body weight increase were seen some of the individuals (Table 1).

The graph showing that the difference between initial and final experiment of ninety days period of 10 individuals shows that there is a peak increase of weight in the individuals 3 and 8 because of the tremendous growth of the individuals in the final stage of the experiment (Figure 2).

The growth rate of 10 individuals of Harpaphe haydeniana at every 15 days interval shows that there is a steady increase of the body weight of each individual (Figure 3). The 15 days interval of experiment the growth was high in the individuals 3 and 8 .

In the case of Xenobolus carnifex the 90 days period of experiment shows that there is about $25 \%$ of the weight increase among the individuals (Table 2). There is a significant differences in growth between the individuals $(\mathrm{F}=0.1385, \mathrm{df}=8.134, \mathrm{p}=0.9962)$. 
Table I Growth rate of Harpaphe haydeniana for the period of 90 days

\begin{tabular}{|c|c|c|c|c|c|c|c|c|c|c|}
\hline \multicolumn{11}{|c|}{ Harpaphe haydeniana } \\
\hline Individuals & $\mathbf{I}$ & 2 & 3 & 4 & 5 & 6 & 7 & 8 & 9 & 10 \\
\hline Initial weight (g) & 0.58 & 0.64 & 0.34 & 0.39 & 0.39 & 0.39 & 0.47 & 0.37 & 0.45 & 0.42 \\
\hline Final weight (g) & 0.85 & 0.85 & 0.75 & 0.74 & 0.63 & 0.55 & 0.66 & 0.77 & 0.65 & 0.67 \\
\hline Difference weight (g) & 0.27 & 0.21 & 0.41 & 0.35 & 0.24 & 0.16 & 0.19 & 0.4 & 0.2 & 0.25 \\
\hline
\end{tabular}

Table 2 Growth rate of Xenobolus carnifex for the period of 90 days

\begin{tabular}{|c|c|c|c|c|c|c|c|c|c|c|}
\hline \multicolumn{11}{|l|}{ Xenobolus carnifex } \\
\hline Individuals & I & 2 & 3 & 4 & 5 & 6 & 7 & 8 & 9 & 10 \\
\hline Initial Weight (g) & 0.93 & 0.86 & 0.82 & 0.78 & 0.72 & 0.8 & 0.98 & 1.06 & 1.36 & 1.35 \\
\hline Final Weight (g) & 1.18 & 1.09 & 1.07 & 1.03 & 0.96 & 1.05 & 1.24 & 1.38 & 1.69 & 1.54 \\
\hline $\begin{array}{l}\text { Difference between Initial and } \\
\text { Final Weight }(\mathrm{g})\end{array}$ & 0.25 & 0.23 & 0.25 & 0.25 & 0.24 & 0.25 & 0.26 & 0.32 & 0.33 & 0.19 \\
\hline
\end{tabular}

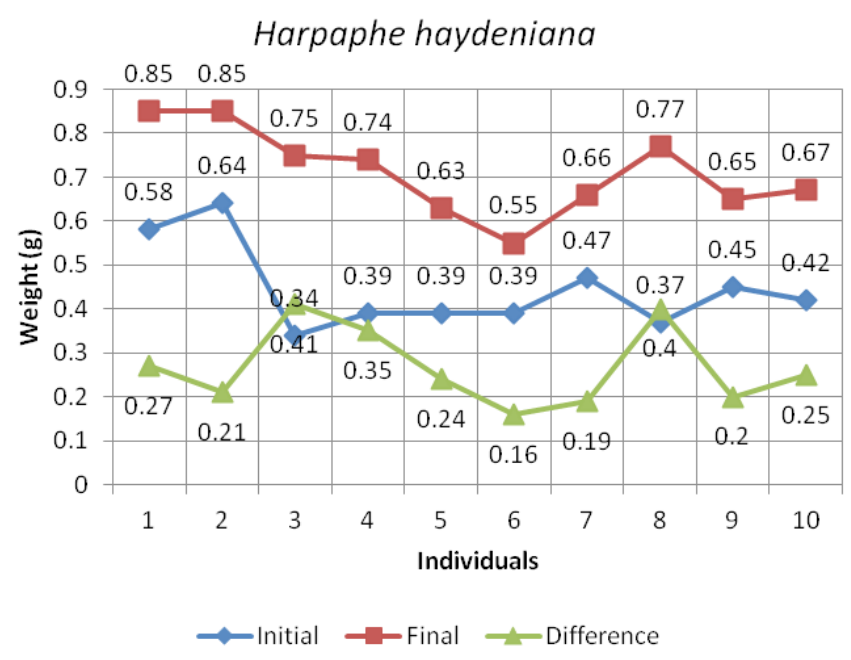

Figure $\mathbf{2}$ Trend of growth rate between individuals of Harpaphe haydeniana.

The graph shows that there is a stable increasing trend was seen in all the stages (initial, final and difference) between the individuals (Figure 4). Similarly the individuals between 15 days interval also shows that there is straight increase of growth (Figure 5).

In the case of Spinotarsus colosseus the increase of body weight of 10 individuals shows that there is a significant differences between the individuals $(\mathrm{F}=0.05101, \mathrm{df}=8.142, \mathrm{p}=0.9999)$. Similarly more than $50 \%$ of the body weight increases were seen in some of the individuals (Table 3 ).

The graph showing that the difference between initial and final experiment of ninety days period of 10 individuals shows that there is a peak increase of weight in the individuals 3,5 and 9 because of the tremendous growth of the individuals in the final stage of the experiment (Figure 6).
Harpaphe haydeniana

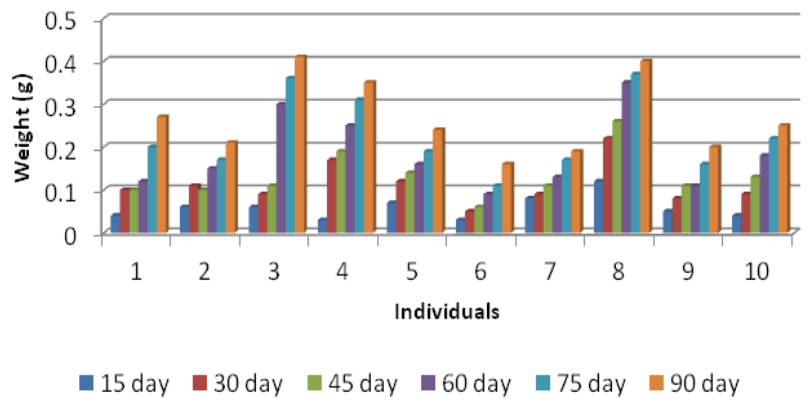

Figure 3 Trend of growth rate between individuals at every 15 days interval of Harpaphe haydeniana.

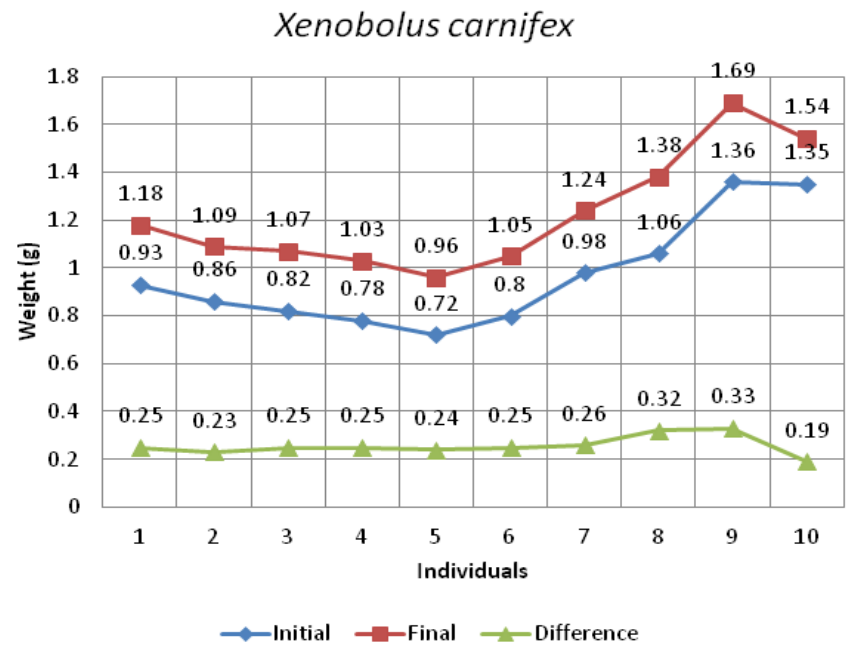

Figure 4 Trend of growth rate between individuals of Xenobolus carnifex. 


\section{Xenobolus carnifex}

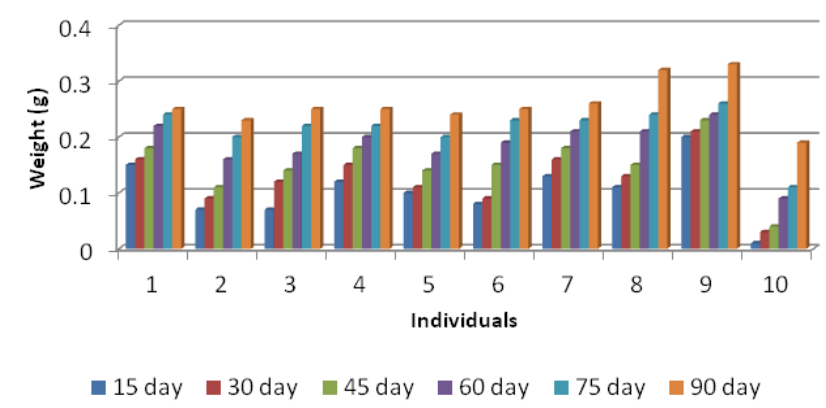

Figure 5 Trend of growth rate between individuals at every 15 days interval of Xenobolus carnifex.

\section{Spinotarsus colosseus}

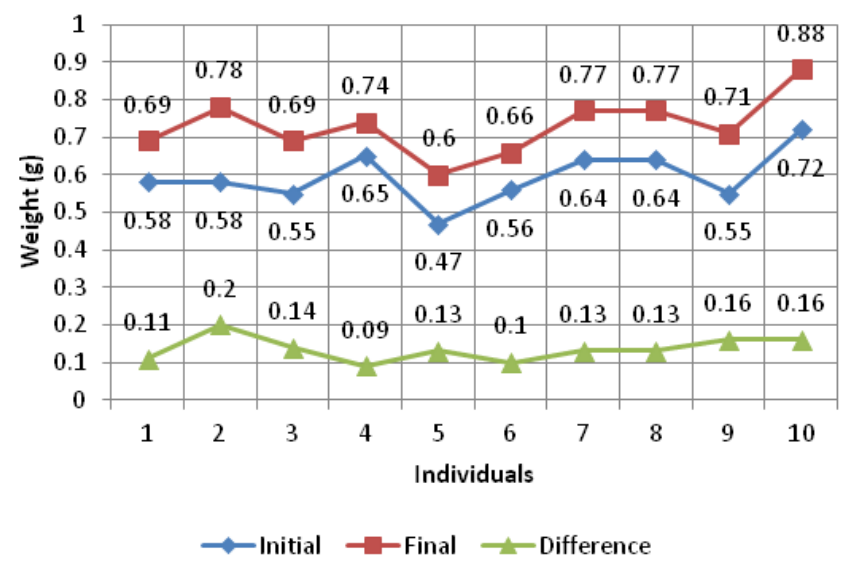

Figure 6 Trend of growth rate between individuals of Spinotarsus colosseus.

\section{Spinotarsus colosseus}

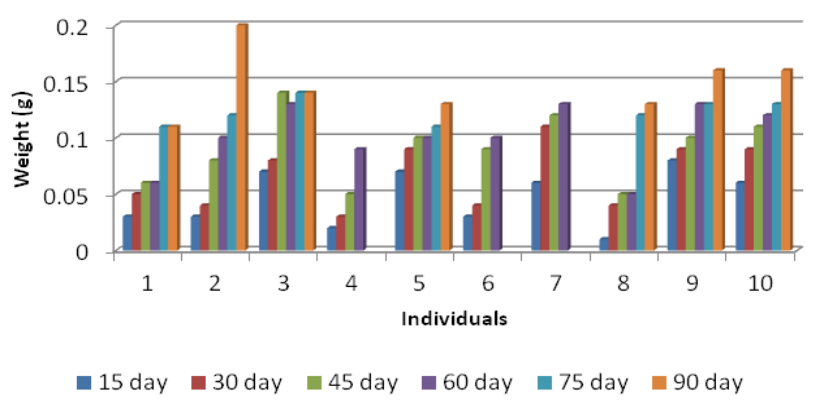

Figure 7 Trend of growth rate between individuals at every 15 days interval of Spinotarsus colosseus.

The growth rate of 10 individuals of Spinotarsus colosseus at every 15 days interval shows that there is a steady increase of the body weight of each individual (Figure 7). The 15 days interval of experiment, the growth was high in the individuals 2, 9 and 10 .

In the case of Narceus americanus the 90 days period of experiment shows that there is about $25 \%$ of the weight increase among the individuals (Table 4). There is a significant differences between the individuals $(\mathrm{F}=0.1308, \mathrm{df}=8.141, \mathrm{p}=0.9969)$.
The graph shows that there is a stable increasing trend was seen in all the stages (initial, final and difference) between the individuals (Figure 8). Similarly the individuals between 15 days interval also shows that there is straight increase of growth (Figure 9).

\section{Narceus americanus}

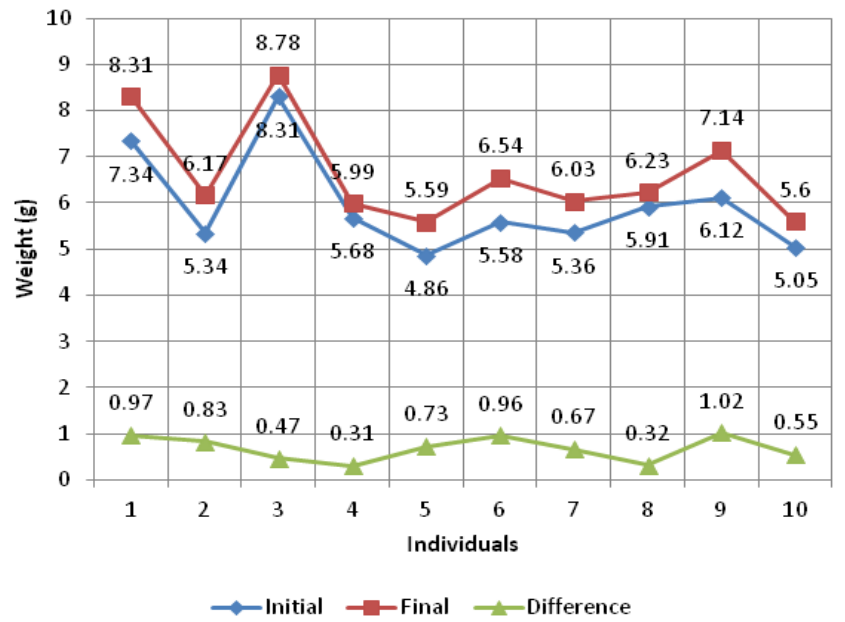

Figure $\mathbf{8}$ Trend of growth rate between individuals of Narceus americanus.

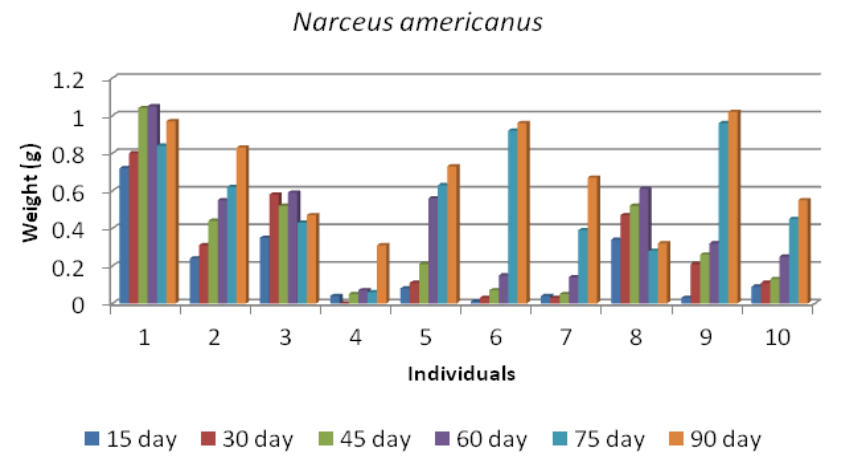

Figure 9 Trend of growth rate between individuals at every I 5 days interval of Narceus americanus.

\section{Food intake and faecal production}

The dry and decayed leaves were provided as food for all the individuals of the millipedes shows that there is positive and negative trends were seen among the individuals (Table 5). The statistical analysis of the food intake and faecal production shows that there is a significant trends $(\mathrm{F}=0.3206, \mathrm{df}=8.121, \mathrm{p}=0.9453)$.

The graph shows that there are positive and negative trends in food intake and faecal production (Figure 10). Figure 11 shows that the total food intake and total growth of 90 days period of Harpaphe haydeniana.

The food provided for all the individuals of the Xenobolus carnifex millipedes shows that there is positive trends were seen among the individuals (Table 6). The statistical analysis of the food intake and faecal production shows that significant trends $(\mathrm{F}=0.3092, \mathrm{df}=8.142$, $\mathrm{p}=0.9505$ ).

The graph shows that there are positive trends in food intake and faecal production (Figure 12). Figure 13 shows that stable trend of the total food intake and total growth of 90 days period of Xenobolus carnifex. 
Table 3 Growth rate of Spinotarsus colosseus for the period of 90 days

\begin{tabular}{|c|c|c|c|c|c|c|c|c|c|c|}
\hline \multicolumn{11}{|l|}{ Spinotarsus colosseus } \\
\hline Individuals & I & 2 & 3 & 4 & 5 & 6 & 7 & 8 & 9 & 10 \\
\hline Initial weight (g) & 0.58 & 0.58 & 0.55 & 0.65 & 0.47 & 0.56 & 0.64 & 0.64 & 0.55 & 0.72 \\
\hline Final weight (g) & 0.69 & 0.78 & 0.69 & 0.74 & 0.6 & 0.66 & 0.77 & 0.77 & 0.71 & 0.88 \\
\hline $\begin{array}{l}\text { Difference between initial and final } \\
\text { weight }(g)\end{array}$ & 0.11 & 0.2 & 0.14 & 0.09 & 0.13 & 0.1 & 0.13 & 0.13 & 0.16 & 0.16 \\
\hline
\end{tabular}

Table 4 Growth rate of Narceus americanus for the period of 90 days

\begin{tabular}{lllllllllll}
\hline Narceus americanus & & & & & & & & & \\
\hline Individuals & $\mathbf{I}$ & $\mathbf{2}$ & $\mathbf{3}$ & $\mathbf{4}$ & $\mathbf{5}$ & $\mathbf{6}$ & $\mathbf{7}$ & $\mathbf{8}$ & $\mathbf{9}$ & $\mathbf{1 0}$ \\
\hline $\begin{array}{l}\text { Initial weight (g) } \\
\text { Final weight (g) }\end{array}$ & 7.34 & 5.34 & 8.31 & 5.68 & 4.86 & 5.58 & 5.36 & 5.91 & 6.12 & 5.05 \\
$\begin{array}{l}\text { Difference between initial and final } \\
\text { weight (g) }\end{array}$ & $\mathbf{8 . 3 1}$ & 6.17 & 8.78 & 5.99 & 5.59 & 6.54 & 6.03 & 6.23 & 7.14 & 5.6 \\
\end{tabular}

Table 5 Differences between food intake and faecal production of Harpaphe haydeniana

\begin{tabular}{|c|c|c|c|c|c|c|c|c|c|c|}
\hline \multicolumn{11}{|l|}{ Harpaphe haydeniana } \\
\hline Individuals & I & 2 & 3 & 4 & 5 & 6 & 7 & 8 & 9 & 10 \\
\hline Total faecal production (g) & 3.37 & 4.15 & 3.21 & 5.15 & 4.54 & 5.52 & 5.51 & 5.02 & 3.57 & 2.98 \\
\hline
\end{tabular}

Table 6 Differences between food intake and faecal production of Xenobolus carnifex

\begin{tabular}{|c|c|c|c|c|c|c|c|c|c|c|}
\hline \multicolumn{11}{|l|}{ Xenobolus carnifex } \\
\hline Individuals & I & 2 & 3 & 4 & 5 & 6 & 7 & 8 & 9 & 10 \\
\hline Total food intake (g) & 4.45 & 4.77 & 5.23 & 4.83 & 6.68 & 4.37 & 2.93 & 6.15 & 5.23 & 3.77 \\
\hline Total faecal production (g) & 2.54 & 2.98 & $\mathrm{I} .84$ & 2.69 & 4.28 & 3.14 & 2.77 & 2.71 & 3.61 & 2.88 \\
\hline $\begin{array}{l}\text { Difference between food } \\
\text { intake and faecal production }(\mathrm{g})\end{array}$ & 1.91 & I.79 & 3.39 & 2.14 & 2.4 & 1.23 & 0.16 & 3.44 & 1.62 & 0.89 \\
\hline
\end{tabular}

\section{Harpaphe haydeniana}

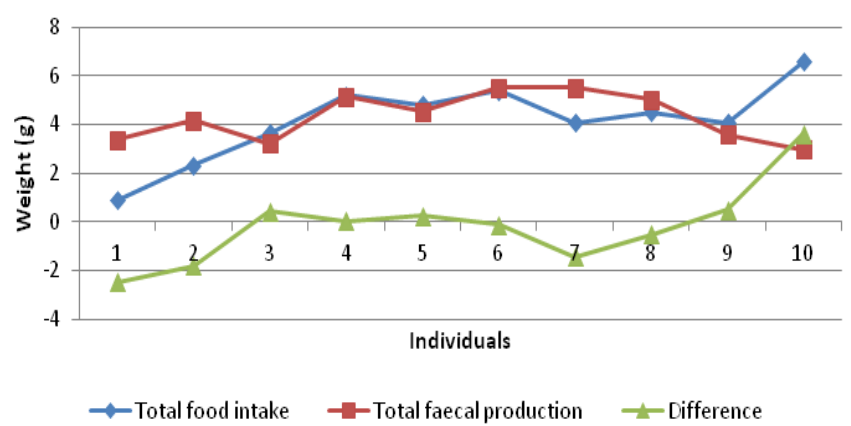

Figure 10 Graph showing the differences between Food intake and faecal production of Harpaphe haydeniana.
The dry and decayed leaves were provided as food for all the individuals of the Spinotarsus colosseus millipedes shows that there is positive and negative trends were seen among the individuals (Table 7). The statistical analysis of the food intake and faecal production shows that significant trends $(\mathrm{F}=0.5196, \mathrm{df}=8.119, \mathrm{p}=0.8259)$.

The graph shows that there are positive and negative trends in food intake and faecal production (Figure 14). Figure 15 shows that the total food intake and total growth of 90 days period of Spinotarsus colosseus.

The food provided for all the individuals of the Narceus americanus millipedes shows that there is positive trends of increasing food intake were seen among the individuals (Table 8). The statistical analysis of the food intake and faecal production shows that significant trends $(\mathrm{F}=0.1308, \mathrm{df}=8.141, \mathrm{p}=0.9969)$.

The graph shows that there are positive trends in food intake and 
faecal production (Figure 16). Figure 17 shows that stable trend of the total food intake and total growth of 90 days period of Xenobolus carnifex.

\section{Harpaphe haydeniana}

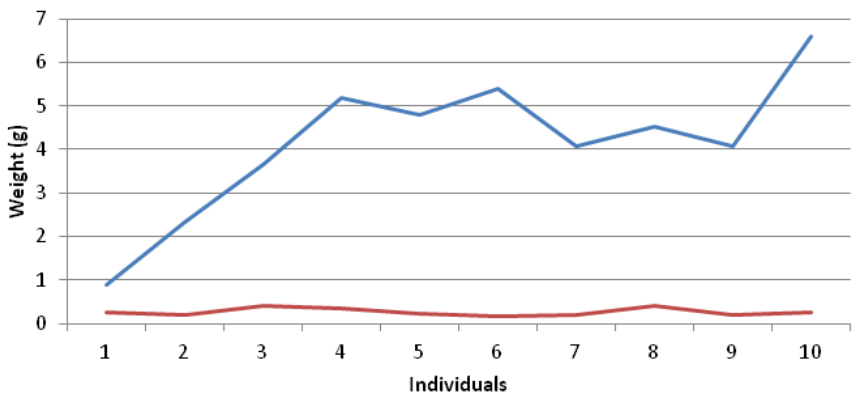

Total food intake Total growth

Figure II Graph showing the total food intake and total growth of Harpaphe haydeniana.

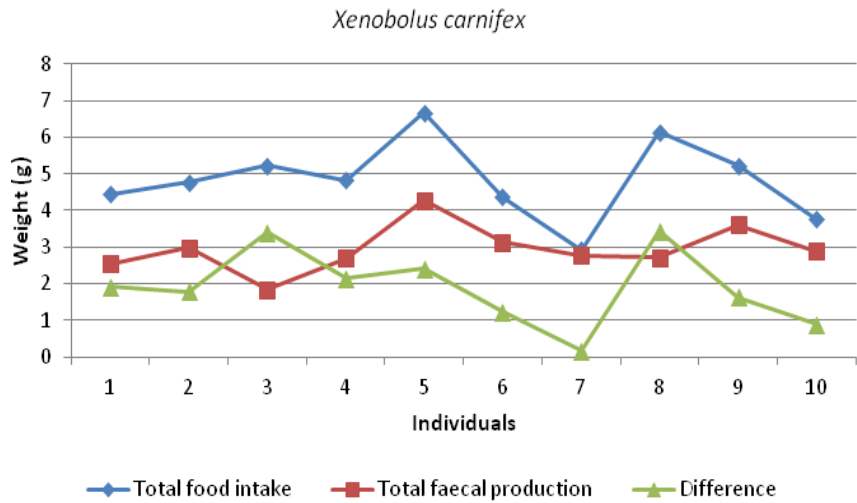

Figure I 2 Graph showing the differences between Food intake and faecal production of Xenobolus carnifex.

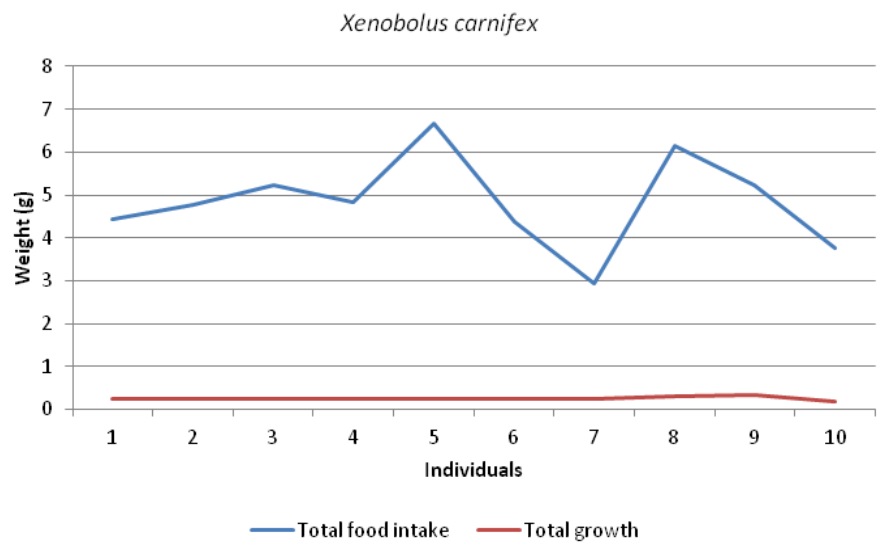

Figure 13 Graph showing the total food intake and total growth of Xenobolus carnifex.

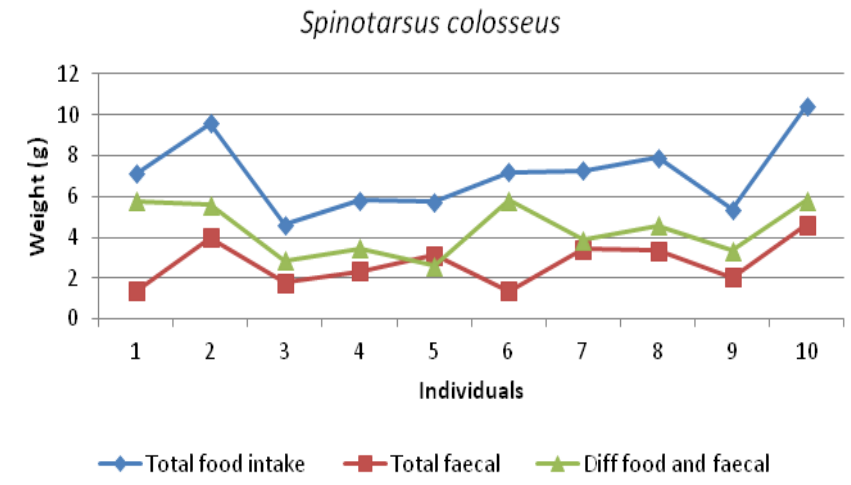

Figure 14 Graph showing the differences between Food intake and faecal production of Spinotarsus colosseus.

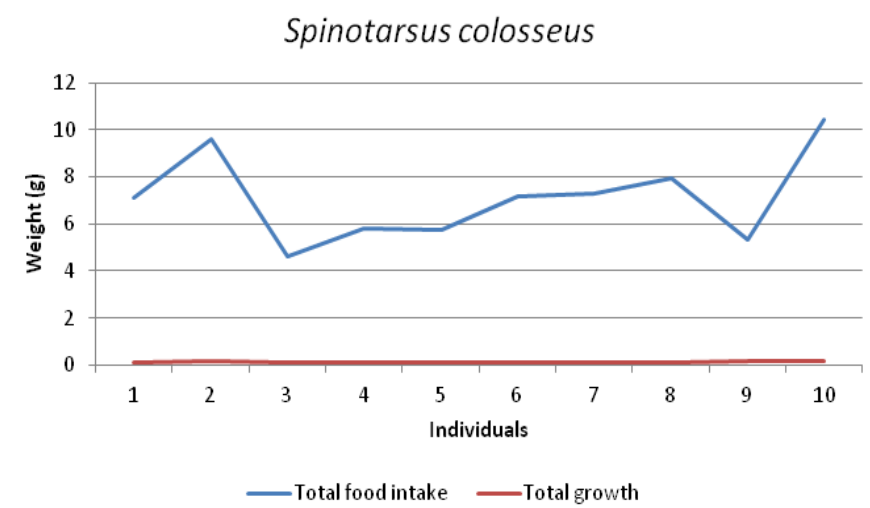

Figure 15 Graph showing the total food intake and total growth of Spinotarsus colosseus.

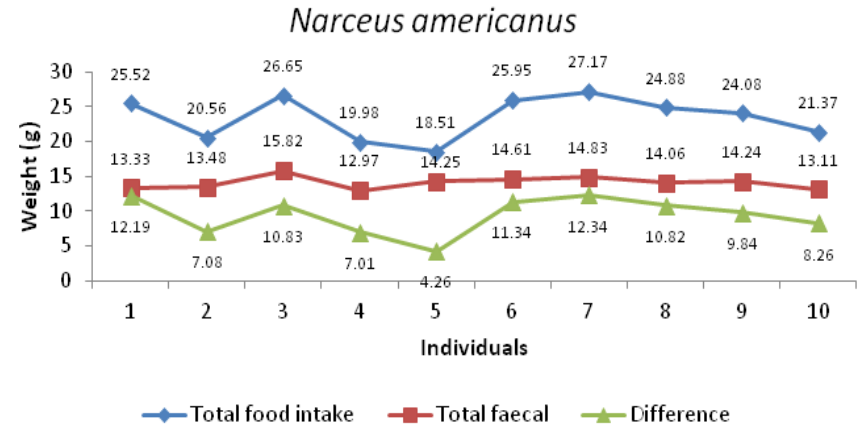

Figure 16 Graph showing the differences between Food intake and faecal production of Narceus americanus.

\section{Discussion}

This study demonstrated that all the four species such as Yellowspotted (Harpaphe haydeniana), Red-spined (Xenobolus carnifes), Colossal slender spined (Spinotarsus colosseus) and American giant, (Narceus americanus) consumed dry and decayed litters. These laboratory results support the results of a field study that showed greater abundance of millipedes in Douglas-fir plots than in western redcedar and western hemlock. ${ }^{13}$ The presence of leaf litters may be an important determinant of habitat distribution of these species of 
millipedes may contribute to significant nutrient release in its habitat. It is not clear which aspects of litter quality determine its palatability to millipedes. It is referred from the previous studies that many ericaceous shrubs, such as salal, are known to produce high levels of allelochemicals ${ }^{14}$ that, if retained in leaf litter, may deter feeding by fauna. However, Neuhauser \& Hartenstein ${ }^{15}$ found no correlation between phenolic content and litter preferences of millipedes or isopods. The food intake and growth rate of these millipedes shows this habitat is suitable for the millipede diversity of various detrivorous animal species.

Table 7 Differences between food intake and faecal production of Spinotarsus colosseus

\begin{tabular}{|c|c|c|c|c|c|c|c|c|c|c|}
\hline Individuals & $\mathbf{I}$ & 2 & 3 & 4 & 5 & 6 & 7 & 8 & 9 & 10 \\
\hline Total food intake $(\mathrm{g})$ & 7.13 & 9.59 & 4.63 & 5.8 & 5.73 & 7.18 & 7.29 & 7.92 & 5.36 & 10.43 \\
\hline Total faecal production (g) & 1.36 & 4 & 1.78 & 2.33 & 3.13 & 1.38 & 3.41 & 3.33 & 2.03 & 4.6 \\
\hline $\begin{array}{l}\text { Difference between food intake } \\
\text { and faecal production }(\mathrm{g})\end{array}$ & 5.77 & 5.59 & 2.85 & 3.47 & 2.6 & 5.8 & 3.88 & 4.59 & 3.33 & 5.83 \\
\hline
\end{tabular}

Table 8 Differences between food intake and faecal production of Narceus americanus

\begin{tabular}{|c|c|c|c|c|c|c|c|c|c|c|}
\hline Narceus americanus & & & & & & & & & & \\
\hline Individuals & I & 2 & 3 & 4 & 5 & 6 & 7 & 8 & 9 & 10 \\
\hline Total food intake (g) & 25.52 & 20.56 & 26.65 & 19.98 & $|8.5|$ & 25.95 & 27.17 & 24.88 & 24.08 & 21.37 \\
\hline Total faecal production (g) & 13.33 & 13.48 & 15.82 & 12.97 & 14.25 & $|4.6|$ & 14.83 & 14.06 & 14.24 & $13.1 \mid$ \\
\hline $\begin{array}{l}\text { Difference between food intake } \\
\text { and faecal production (g) }\end{array}$ & 12.19 & 7.08 & 10.83 & 7.01 & 4.26 & II.34 & 12.34 & 10.82 & 9.84 & 8.26 \\
\hline
\end{tabular}

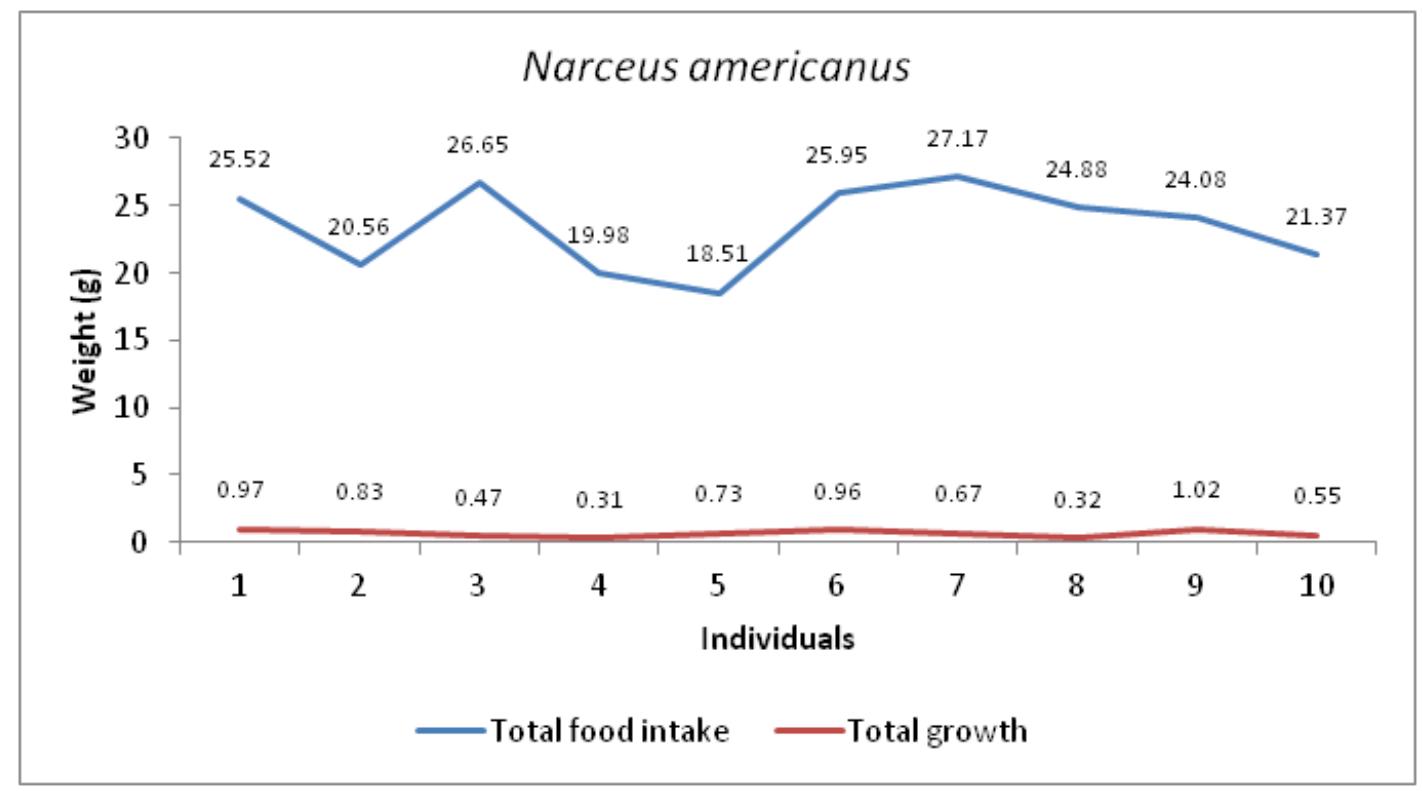

Figure 17 Graph showing the total food intake and total growth of Narceus americanus.

The higher litter intake per body weight of millipedes may be explained by the lower resource quality of litter compared with the deciduous litter used in most European studies. Extrapolations of laboratory results to field consumption rates provide only conservative approximations, as pointed out by Dangerfield ${ }^{16}$. Most controlled studies, including ours, may exaggerate levels of coprophagy and underestimate actual field consumption rates. Under laboratory conditions, millipedes have restricted feeding choices and may be 
forced to consume their own food at greater rates than under natural conditions. ${ }^{16}$ Furthermore, annual litter fall is likely very conservative, because millipede densities are usually underestimated by field surveys, so our values of $2 \mathrm{~g} / \mathrm{m}^{2}$ may be on the low side. In addition to millipedes, other invertebrates including earthworms, molluscs, isopods, arthropods, and other micro organisms are expected to feed on litter. For example, in Vancouver Island, another large Xystodesmid millipede (Tubaphe levii Causey) was found on mesic sites ${ }^{17,18}$ and likely plays a similar role in litter breakdown. We conclude, therefore, that at least a major part of the litter produced in the study sites is probably consumed and thus transformed by soil macrofauna.

\section{Conclusion}

It is concluded that millipedes can impact leaf litter decomposition both directly and indirectly, but the extent of their effect depends on their density and the quality of the substrate (leaf lignin content). Directly, it is clear that millipedes fragment litter, which in some cases has been shown to indirectly increase microbial biomass. It is observed that we could not find an increase but a decrease of soil microbial biomass over time, yet microbial biomass was not affected by the presence of millipedes, suggesting that other factors might have been driving this trend. Millipedes are not the only arthropods influencing decomposition, and their interactions with other organisms in their natural environment could affect the extent of their influence. Notwithstanding, it is suggested that the results of this experiment can be applied to millipedes in their natural setting, further confirming millipedes as important components of soil ecosystems and nutrient cycling. Conservation of these millipedes is very important because there is no doubt they are the friend of farmers.

\section{Acknowledgments}

The authors are very much indebted to the staff members, Department of Zoology and the peoples rendered their help in various stages of the study.

\section{Conflicts of interest}

The authors declare there are no conflicts of interest.

\section{References}

1. Anderson JM, Ineson P, Huish SA. Nitrogen and cation mobilization by soil fauna feeding on leaf litter and soil organic matter from deciduous woodlands. Soil Biol Biochem. 1983;15(4):463-467.

2. Ponge JF. Heterogeneity in soil animal communities and the development of humus forms. In: Rastm N, Bauhus J, editors. Going underground - ecological studies in forest soils. Trivandrum: Research Signpost; 1999:33-44.
3. Hopkin SP, Read HJ. The biology of millipedes. Oxford University Press, Oxford. 1992.

4. Golovatch SI, Hoffman RL, de Morais, JW. Identification plate for the millipede orders populating the neotropical region south of Central Mexico (Myriapoda, Diplopoda). Studies on the Neotropical Fauna and Environment. 1995;30:159-164.

5. Kime RD, Golovatch S. Trends in the ecological strategies and evolution of millipedes (Diplopoda). Biol J Linn Soc. 2000;69(3):333349 .

6. Attems C. Diplopods of India. Calcutta, Zoological Survey of India: Memoirs of the Indian Museum. 1936;11:133-167.

7. Achar KP. Analysis of male meiosis m seven species of Indian pillmillipede (Diplopoda Myriapoda). Caryologia. 1986;39:89-101.

8. Madan B, Kiss I, Korsos Z. Community structure parameters of millipedes (Diplopoda) in five different habitats. Annales HistoricoNaturales Musei Nationalis Hunganci. 1996;88:79-87.

9. Hoffman RL. A new millipede of the genus Gonographis from an inundation forest near Manaus (Pyrgodesmidae). Amazoniana. 1985;9(2):234-246.

10. Alagesan P, Ramanathan B. Diversity of millipedes in Alagar Hills Reserve Forest in Tamil Nadu, India. International Journal of Biodiversity. 2013:1-5.

11. Waldbauer GP. The consumption and utilization of food by insects. Advances in insect physiology. 1968:5:229-288.

12. Chaudhury MFB. Insect physiology and biochemistry. Nairobi: International Centre of Insect Physiology and Ecology (ICIPE); 1994:202.

13. Prescott CE, Cárcamo HA. The influence of soil fauna on ecosystem processes in forests of British Columbia. Unpublished final report. Forest Renewal British Columbia, Victoria. Rep. PA97268-9RE. 1999.

14. Prescott CE, Preston CM. Nitrogen mineralization and decomposition in forest floors in adjacent plantations of western redcedar, western hemlock, and Douglas-fir. Can J For Res. 1994;24:2424-2431.

15. Neuhauser EF, Hartenstein R. Phenolic content and palatability of leaves and wood to soil isopods and diplopods. Pedobiologia. 1978;18:99-109.

16. Dangerfield JM. Ingestion of leaf litter by millipedes: the accuracy of laboratory estimates for predicting litter turnover in the field. Pedobiologia. 1994;38:262-265.

17. Shelley RM. A new milliped of the genus Metaxycheir from the Pacific coast of Canada (Polysdesmidae: Xystodesmidae), with remarks on the tribe Chonaphini and the western Canadian and Alaskan diplopod fauna. Can J Zool. 1990;68(11):2310-2322.

18. Shelley RM. The milliped genus Underwoodia (Chordeumatida: Caseyidae). Can J Zool. 1993;71(1):168-176. 